\title{
GMR
}

\section{Genetic diversity analysis of Croton antisyphiliticus Mart. using AFLP molecular markers}

\author{
T.G. Oliveira' ${ }^{1}$ A.M.S. Pereira ${ }^{2}$, J.S. Coppede ${ }^{2}$, S.C. França ${ }^{2}$, L.C. Ming ${ }^{1}$ and \\ B.W. Bertoni \\ 1Departamento de Horticultura, Universidade Estadual Paulista, Botucatu, \\ SP, Brasil \\ 2Departemento de Biotecnologia de Plantas, Universidade de Ribeirão Preto, \\ Ribeirão Preto, SP, Brasil \\ Corresponding author: A.M.S. Pereira \\ E-mail: apereira@unaerp.br \\ Genet. Mol. Res. 15 (1): gmr.15017461 \\ Received August 17, 2015 \\ Accepted November 6, 2015 \\ Published February 19, 2016 \\ DOI http://dx.doi.org/10.4238/gmr.15017461
}

ABSTRACT. Croton antisyphiliticus Mart. is a medicinal plant native to Cerrado vegetation in Brazil, and it is popularly used to treat urogenital tract infections. The objective of the present study was to assess the genetic variability of natural $C$. antisyphiliticus populations using AFLP molecular markers. Accessions were collected in the states of Minas Gerais, São Paulo, and Goiás. The genotyping of individuals was performed using a LI-COR ${ }^{\circledR}$ DNA Analyzer 4300. The variability within populations was found to be greater than the variability between them. The $F_{\mathrm{ST}}$ value was 0.3830 , which indicated that the populations were highly structured. A higher percentage of polymorphic loci $(92.16 \%)$ and greater genetic diversity were found in the population accessions from Pratinha-MG. Gene flow was considered restricted $\left(N_{\mathrm{m}}=1.18\right)$, and there was no correlation between genetic and geographic distances. The populations of $C$. antisyphiliticus 
exhibited an island-model structure, which demonstrates the vulnerability of the species.

Key words: Euphorbiaceae; Medicinal plant; Cerrado; Conservation; LI-COR

\section{INTRODUCTION}

Habitat destruction and fragmentation are among the major anthropic impacts that affect ecosystems (Young et al., 1996; Young and Clarke, 2000). Fragmentation not only reduces the population effective size and the wealth of the species, but it also increases the spatial isolation among them (Young et al., 1996). Plants can live in naturally fragmented habitats, and they are capable of adapting to new conditions associated with this process. However, the intensity by which anthropic fragmentation has occurred during the past decades has made it difficult for plants to adapt to changes due to partial habitat destruction (Lienert, 2004). Therefore, fragmentation threatens the survival of many species, and it can cause the extinction of local populations (Ehrlich and Wilson, 1991; Young and Clarke, 2000).

Several species of the Cerrado biome have been threatened by fragmentation, including Croton antisyphiliticus Mart., which is popularly known as "pé-de-perdiz". The roots of this plant are widely used by the native people to treat urogenital tract infections (Munhoz and Felfili, 2007).

The practice of extractivism predominantly includes those plants whose active components are in their roots. These species become more vulnerable after being pulled up, and they subsequently disappear.

The use of tools for the measurement of genetic variability, such as molecular markers, is important for the determination of biodiversity conservation strategies (Avise, 2010). Several markers are analyzed using PCR, including amplified fragment length polymorphism (AFLP) markers (Guimarães et al., 2009). The AFLP marker technique is robust, safe, and highly reproducible, and it allows the detection of high levels of polymorphism; therefore, it is widely used to assess the genetic variation in natural populations (Vos et al., 1995; Metin et al., 2014). Historically, AFLP has been used to analyze various species, including Hipericum perforatum L. (Percifield et al., 2007), Tribulus terrestris L. (Sarwat et al., 2008), Croton draco Schltdl. and Cham. (Farías et al., 2009), Anacardium humile St. Hill. (Londe et al., 2010), Maytenus ilicifolia Mart. ex Reis (Ribeiro et al., 2010), Stryphnodendron adstringens (Mart.) Coville (Mendonça et al., 2012), and Palicourea rigida (Silva et al., 2013).

Therefore, the objective of the present study was to assess the genetic diversity of natural populations of $C$. antisyphiliticus using AFLP molecular markers to establish conservation strategies for the species.

\section{MATERIAL AND METHODS}

Young leaves were collected from 20 individuals from each natural population in the counties of Catalão and Jataí (GO), Sacramento, Pratinha and São Gonçalo (MG), and Pedregulho (SP). The choice of the collection areas was based on the natural occurrence of the species, and species localization was determined with GPS. The leaves were stored in paper bags and kept in a freezer at $-20^{\circ} \mathrm{C}$ until extractions were performed. 
The analyses were conducted at the Molecular Biology Laboratory of the Department of Medicinal Plant Biotechnology of Universidade de Ribeirão Preto.

Due to the difficulty in obtaining intact genetic material, two DNA extraction protocols were evaluated for $C$. antisyphiliticus. The first was proposed by Doyle and Doyle (1987), and the second was designed by Deshmukh et al. (2007). Both methods were performed with modifications.

\section{AFLP protocols}

AFLP analyses were performed using the method described by Vos et al. (1995), which utilizes the commercial IRDye ${ }^{\circledR}$ fluorescent AFLP ${ }^{\circledR}$ Kit designed for large plant genome analysis. This method also included a protocol (LI-COR Biosciences, Lincoln, NE, USA) The combination of eight primers included E-ACA/M-CGA, E-AAC/M-CTA, E-AAG/M-CAT, E-ACC/M-CTG, E-ACG/MCAG, E-AGC/M-CTA, E-AGG/M-CAT, and E-ACT/M-CTG, and the AFLP amplification products were loaded on a polyacrylamide gel $(6.5 \%)$. We visualized the results using an automated AFLP analysis program (LI-COR SAGA ${ }^{\mathrm{Mx}}$ v.3.3). Only clear and unambiguous bands were scored and numbered for each fragment based on the molecular weight.

\section{Statistical analysis}

The resulting binary data were used to estimate the allele frequencies, which were then subjected to variance decomposition analysis of total genetic variance both within and between the populations (AMOVA). This analysis allowed the assessment of the variability structure, as proposed by Excoffier et al. (2005). The descriptive analysis of total variability was performed by calculating the percentage of polymorphic loci and Nei's gene diversity index (h). The unweighted pair group method with arithmetic mean (UPGMA) was used for both the analysis of grouping and the assessment of genetic divergence between the study populations, based on the $\mathrm{h}$ values ( $\mathrm{Nei}$, 1978). The geographic distance was calculated using the TrackMaker v.13.8 software, and Mantel's test was performed with 1000 simulations. The programs Popgene 32 and Genes v 2009.7.0 were used for these analyses.

The genotypic structure was assessed by performing principal coordinate analysis (PCoA), using the GenAIEx v6.5 (Peakall and Smouse, 2006) and STRUCTURE v.2.2.4 (Pritchard et al., 2000) software. Genotypic structure was also determined using grouping analyses based on Bayesian and admixture models with a burn-in of 200,000 followed by a run-length of 500,000, and the analysis included five independent interactions and K-values ranging from 1 to 7 . With this, we sought to determine the number of genetic groups based on the criterion proposed by Evanno et al. (2005).

\section{RESULTS}

\section{DNA extraction}

The protocol proposed by Deshmukh et al. (2007) resulted in genetic material with the highest integrity as well as a mean DNA concentration of $393.43 \mathrm{ng} / \mu \mathrm{L}$.

Analyses using the SAGAMX program enabled the visualization of 255 bands, and the use of eight primer combinations yielded a number of bands (all polymorphic) per combination that 
ranged between 10 to 51 (Table 1). Regarding the percentage of polymorphism, the populations from Pratinha and Jataí showed the highest values (92.16 and $91.76 \%$, respectively), whereas the population from Sacramento had the lowest value $(78.43 \%)$ (Table 2$)$.

Values of $\mathrm{h}$ ranged from 0.2733 to 0.3540 , and the Shannon's index values ranged from 0.4136 to 0.5195 . The correlation coefficient between both indices was 0.998 , which demonstrated a strong positive correlation. The population from Pedregulho exhibited the lowest diversity for both indices, whereas those from Catalão and Pratinha had the highest values (Table 2). The Pratinha population also showed the best results for the following parameters: percentage of polymorphic loci, number of observed alleles, and number of effective alleles.

The variability within the population was greater $(61.97 \%)$ than that between populations (38.03\%). The gene flow between populations was low $\left(N_{\mathrm{m}}=1.18\right)$.

The allele fixation index $\left(F_{\mathrm{ST}}\right)$ was 0.3803 (Table 3$)$, which indicated a very high value for genetic population structuring based on the limit of $>0.25$ proposed by Wright (1978). The spatial pattern determined by Mantel's test based on 1000 permutations was $r=0.17$, thus indicating the absence of a significant correlation between geographic and genetic distances.

Analysis of the dendrogram and PCoA indicated the formation of three groups: 1) populations from Catalão and Jataí; 2) populations from São Gonçalo and Pedregulho; and 3) populations from Sacramento and Pratinha (Figures 1 and 2).

The results generated by the STRUCTURE software distributed the 120 individuals into six genetic groups (Figure 3). Regarding the STUCTURE results, the same color for different genotypes indicates that they belong to the same group, and different colors for the same individual indicate the percentage of genome shared by each group.

Table 1. Nucleotide combination and number of amplified fragments.
\begin{tabular}{l|c}
\hline EcoRI-Msel combination & Total number of fragments \\
\hline ACA/CGA & 51 \\
\hline AAC/CTA & 39 \\
\hline AAG/CAT & 41 \\
\hline ACC/CTG & 42 \\
\hline ACG/CAG & 28 \\
\hline AGC/CTA & 24 \\
\hline AGG/CAT & 20 \\
\hline ACT/CTG & 10 \\
\hline TOTAL & 255 \\
\hline MEAN & 31.87 \\
\hline
\end{tabular}

Table 2. Basic descriptive statistics for Croton antisyphiliticus populations assessed using AFLP markers.

\begin{tabular}{l|c|c|c|c|c|c}
\hline Populations & $\mathrm{N}$ & $N_{\mathrm{A}}$ & $\mathrm{P}$ & $N_{\mathrm{E}}$ & $\mathrm{h}$ & $\mathrm{I}$ \\
\hline Catalão & 20 & 1.9176 & 91.76 & 1.5583 & 0.3209 & 0.4770 \\
\hline Jataí & 20 & 1.8627 & 86.27 & 1.5407 & 0.3104 & 0.4602 \\
\hline Sacramento & 20 & 1.7843 & 78.43 & 1.4931 & 0.2841 & 0.4212 \\
\hline Pratinha & 20 & 1.9216 & 92.16 & 1.6262 & 0.3540 & 0.5195 \\
\hline São Gonçalo & 20 & 1.8627 & 84.71 & 1.4916 & 0.2896 & 0.4358 \\
\hline Pedregulho & 20 & 1.8471 & 86.27 & 1.4614 & 0.2733 & 0.4136 \\
\hline Mean & 20 & 1.8660 & 86.60 & 1.5286 & 0.3054 & 0.4546 \\
\hline
\end{tabular}

Mean size of sample $(\mathrm{N})$; number of observed alleles $\left(N_{\mathrm{A}}\right)$; percentage of polymorphic alleles $(\mathrm{P})$; number of effective alleles $\left(N_{\mathrm{E}}\right)$; Nei's genetic diversity $(1978)(\mathrm{h})$; Shannon's index (I). 
Table 3. Analysis of molecular variance (AMOVA) between and within populations of Croton antisyphiliticus assessed using AFLP markers.

\begin{tabular}{l|c|c|c|c|c|c|c}
\hline Source of variation & d.f. & S.S. & S.M.S & Components of variance & \% total of variance & P & Statistics - PHIst \\
\hline Between populations & 5 & 2571.325 & 514.265 & 23.776 & 38.0293 & $<0.001$ & 0.3803 \\
\hline Within population & 114 & 4416.85 & 38.7242 & 38.7743 & 61.9707 & - & - \\
\hline Total & 119 & 6988.175 & 58.7242 & 62.5203 & 100.00 & - & - \\
\hline
\end{tabular}

Degrees of freedom (d.f.); sum of squares (S.S.); sum of mean squares (S.M.S.); significance level for genetic variation estimation using 1000 permutations $(\mathrm{P})$; genetic variation estimated for the variation source analogue to Wright's $F_{\mathrm{ST}}$ $\left(\mathrm{PHI}_{\mathrm{st}}\right)$. Results were obtained using the GENES software.

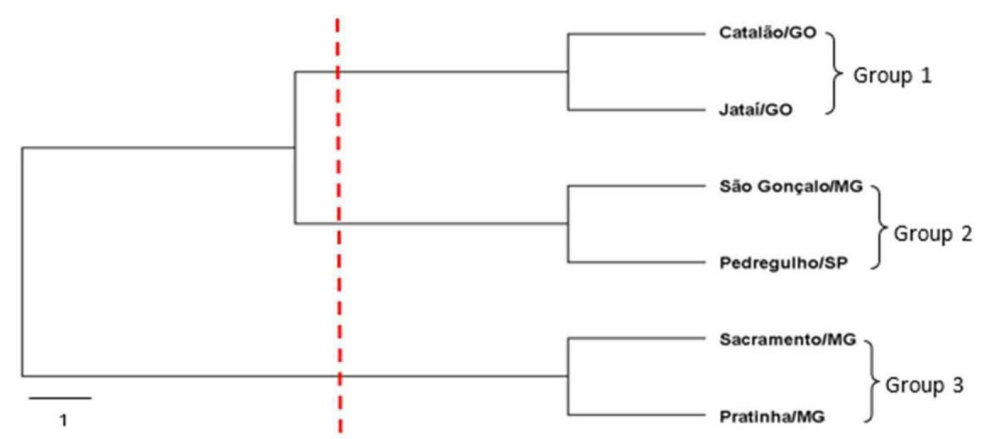

Figure 1. Dendrogram of Croton antisyphiliticus populations.

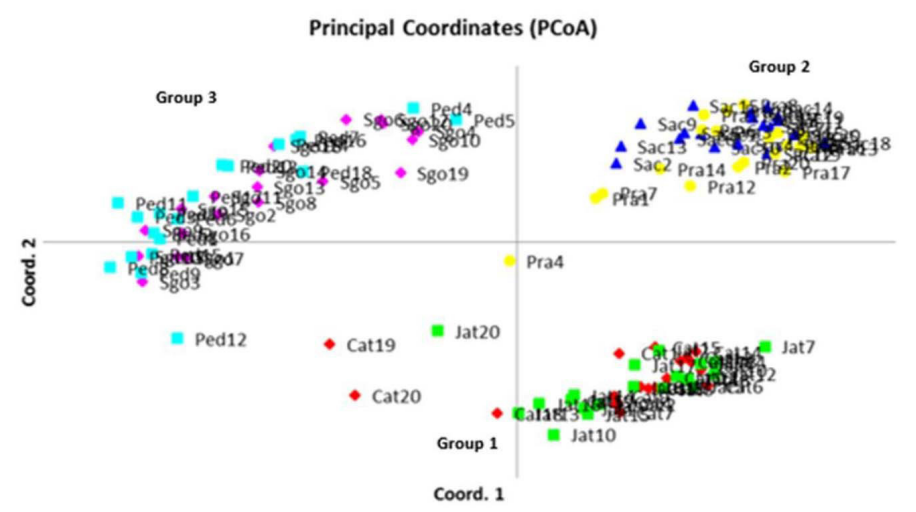

Figure 2. Results of the principal coordinate analysis (PCoA) of Croton antisyphiliticus populations.

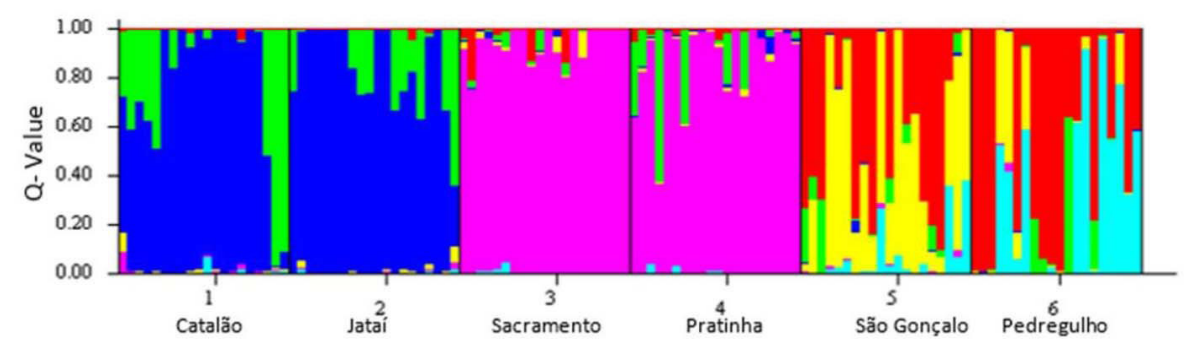

Figure 3. Composition of genetic groups of Croton antisyphiliticus populations identified by the STRUCTURE analysis. 


\section{DISCUSSION}

It has been reported that it is difficult to obtain intact DNA from tropical species because of the presence of secondary composites, particularly those in the phenolics class (Rath et al., 1998; Deshmukh et al., 2007). During the C. antisyphiliticus DNA extraction process, both viscosity and oxidation were observed in the samples, and this problem was solved using the protocol developed by Deshmukh et al. (2007). The effectiveness of this protocol is related to the higher number of washings to which the samples were subjected.

The results indicated a high percentage of polymorphism in C. antisyphiliticus individuals, which is likely related to the pollination type and seed dispersal. Although no studies of the phenology of this species have been conducted, Croton research has shown the predominance of cross-pollination and seed dispersal by insects (Domínguez and Bullock, 1989; Almeida et al., 2003), and this may be a pattern of the genus that explains the high level of polymorphism in $C$. antisyphiliticus.

As gene flow is directly related to the types of reproduction and dispersal that occur in a species, and this case of $C$. antisyphiliticus dispersal is mainly performed by ants. This is because its seed has a structure called a caruncula, which is capable of attracting these insects (Leal et al., 2007). Although Croton studies have demonstrated that pollen is primarily dispersed by wind and secondarily by insects (especially bees) (Dominguez and Bullock, 1989; Juhász et al., 2009), the present study provides evidence that $C$. antisyphiliticus has low $N_{\mathrm{m}}$. This result is probably due to the difficulty associated with pollen and seed dispersal, since the localization of the collected individuals was restricted to small bands of vegetation along roads and permanent protection areas.

Smouse et al. (2001) stated that the greater the structuring, the lower the dispersal and $N_{\mathrm{m}}$. This was evidenced with the high allele fixation value $\left(F_{\mathrm{ST}}=0.3803\right)$, indicating that $C$. antisyphiliticus populations are highly structured. According to Frankham et al. (2007), when $F_{\mathrm{ST}}$ values are high, the dispersal capacity is low. Moreover, studies have also suggested that the greater the probability of the populations becoming endogamic, the lower the probability that the species will adapt to environmental changes, which leads to a higher risk of extinction (Ellstrand and Elam, 1993; Silva et al., 2013). Based on these assumptions, the values of both $F_{\mathrm{ST}}$ and $N_{\mathrm{m}}$ indicated that the $C$. antisyphiliticus populations at the collection sites were highly anthropic and fragmented regions, which resulted in island-model structured populations.

The data obtained from the STRUCTURE, dendrogram, and PCOA analyses reflected how the populations were structured, providing evidence for the fragmentation of $C$. antisyphiliticus populations into smaller ones (Figures 1,2, and 3). Moreover, Figure 3 shows a trend in which the São Gonçalo and Pedregulho populations are divided into sub-populations, because virtually $50 \%$ of their genomes were assigned to each gene group. This finding deserves special attention, because a consequence of fragmentation is the restriction of individuals to small areas, which will isolate them partially or completely from other populations. Research has shown that fragmentation, from the genetic point of view, can alter the $N_{\mathrm{m}}$ among populations in such a way that they become more susceptible to endogamic processes and genetic drift (Young et al., 1996).

In addition, the effective population size is reduced with habitat fragmentation, because even individuals carrying favorable allelic compositions may be lost. Therefore, over the generations, the remaining individuals begin to accumulate identical alleles as a result of high endogamy levels, and this reduces the adaptive value of these individuals (Young et al., 1996). Based on the composition 
data of the groups identified by the STRUCTURE analysis, it was possible to establish a collection strategy by prioritizing populations from Catalão, Sacramento, and Pedregulho, because these showed greater genetic diversity.

\title{
Conflicts of interest
}

The authors declare no conflict of interest.

\section{ACKNOWLEDGMENTS}

\author{
Research supported by UNAERP and the Conselho Nacional de Desenvolvimento \\ Científico e Tecnológico (CNPQ).
}

\section{REFERENCES}

Almeida D, Marchini LC, Sodré GS, D’Ávila M, et al. (2003). Plantas visitadas por abelhas e polinização. Piracicaba: ESALQ Divisão de Biblioteca e Documentação - (Série Produtor Rural, Edição Especial) ISBN 1414-4530.

Avise JC (2010). Perspective: conservation genetics enters the genomics era. Conserv. Genet. 11: 665-669. http://dx.doi. org/10.1007/s10592-009-0006-y

Deshmukh VP, Thakare PV, Chaudhari US and Gawande PA (2007). A simple method for isolation of genomic DNA from fresh and dry leaves of Terminalia arjuna (Roxb.) Wight and Arnot. Electron. J. Biotechnol. 10: 468-472. http://dx.doi. org/10.2225/vol10-issue3-fulltext-5

Domínguez CA and Bullock SH (1989). La reproducción de Croton suberosus (Euphorbiaceae) en luz y sombra. Rev. Biol. Trop. 37: 1-10.

Doyle JJ and Doyle JL (1987). Isolation of plant DNA from fresh tissue. Focus 12: 13-15.

Ehrlich PR and Wilson E (1991). Biodiversity studies: science and policy. Science 253: 758-762. http://dx.doi.org/10.1126/ science.253.5021.758

Ellstrand NC and Elam DR (1993). Population genetic consequences of small population size: implications for plant conservation. Annu. Rev. Ecol. Syst. 24: 217-242. http://dx.doi.org/10.1146/annurev.es.24.110193.001245

Evanno G, Regnaut S and Goudet J (2005). Detecting the number of clusters of individuals using the software STRUCTURE: a simulation study. Mol. Ecol. 14: 2611-2620. http://dx.doi.org/10.1111/j.1365-294X.2005.02553.x

Excoffier L, Laval G and Schneider S (2005). Arlequin (version 3.0): an integrated software package for population genetics data analysis. Evol. Bioinform. Online 1: 47-50.

Farías FR, Williamson JS, Rodríguez SV, Angeles G, et al. (2009). Bark anatomy in Croton draco var. draco (Euphorbiaceae). Am. J. Bot. 96: 2155-2167. http://dx.doi.org/10.3732/ajb.0900035

Frankham R, Ballou JD and Brioscoe DA (2007). A primer of conservation genetics. Cambridge University Press, Cambridge.

Guimarães C, de Magalhães JV, Lanza M and Schuster I (2009). Marcadores moleculares e suas aplicações no melhoramento genético. Inf. Agro. 30: 253.

Juhász ACP, Pimenta S, Soares BO, Morais DDLB, et al. (2009). Biologia floral e polinização artificial de pinhão manso no norte de Minas Gerais. Pesquisa Agropecu. Bras. 44: 1073-1077. http://dx.doi.org/10.1590/S0100-204X2009000900001

Karakaş Metin O, Türktaş M, Ertuğrul F and Kaya E (2014). Use of fluorescent-based amplified fragment length polymorphism to resolve phylogenetic relationships of Colchicum species from Turkey. Genet. Mol. Res. 13: 1480-1490. http://dx.doi. org/10.4238/2014.March.6.6

Leal IR, Wirth R and Tabarelli M (2007). Seed dispersal by ants in the semi-arid Caatinga of North-East Brazil. Ann. Bot. (Lond.) 99: 885-894. http://dx.doi.org/10.1093/aob/mcm017

Lienert J (2004). Habitat fragmentation effects on fitness of plant populations-a review. J. Nat. Conserv. 12: 53-72. http://dx.doi. org/10.1016/j.jnc.2003.07.002

Londe LN, Ribeiro EB, Souza CSD, Kerr WE, et al. (2010). Divergência genética entre populações de Anacardium humile St. Hill. por marcadores AFLP. Circ. Tec. EPAMIG 105: 1-3.

Mendonça PC, Bertoni BW, Amui SF, Giuliatti S, et al. (2012). Genetic diversity of Stryphnodendron adstringens (Mart.) Coville determined by AFLP molecular markers. Biochem. Syst. Ecol. 41: 16-20. http://dx.doi.org/10.1016/j.bse.2011.12.007

Munhoz CBR and Felfili JM (2007). Florística do estrato herbáceo-subarbustivo de um campo limpo úmido em Brasília, DF, 
Brasil. Biota Neotrop. 7: 205-215. http://dx.doi.org/10.1590/\$1676-06032007000300022

Nei M (1978). Estimation of average heterozygosity and genetic distance from a small number of individuals. Genetics 89 : 583-590.

Peakall ROD and Smouse PE (2006). GENALEX 6: genetic analysis in Excel. Population genetic software for teaching and research. Mol. Ecol. Notes 6: 288-295. http://dx.doi.org/10.1111/j.1471-8286.2005.01155.x

Percifield RJ, Hawkins JS, McCoy JA, Widrlechner MP, et al. (2007). Genetic diversity in Hypericum and AFLP Markers for species-specific identification of H. perforatum L. Planta Med. 73: 1614-1621. http://dx.doi.org/10.1055/s-2007-993749

Pritchard JK, Stephens M and Donnelly P (2000). Inference of population structure using multilocus genotype data. Genetics 155: 945-959.

Rath P, Rajaseger G, Goh CJ and Kumar PP (1998). Phylogenetic analysis of Dipterocarps using random amplified polymorphic DNA markers. Ann. Bot. (Lond.) 82: 61-65. http://dx.doi.org/10.1006/anbo.1998.0652

Ribeiro MV, Bianchi VJ, Rodrigues ICS, Mariot MP, et al. (2010). Diversidade genética entre acessos de espinheira-santa (Maytenus ilicifolia Mart. ex Reis.) coletados no estado do Rio Grande do Sul, Brasil. Rev. Bras. Plantas Med 12: 443451. http://dx.doi.org/10.1590/S1516-05722010000400007

Sarwat M, Das S and Srivastava PS (2008). Analysis of genetic diversity through AFLP, SAMPL, ISSR and RAPD markers in Tribulus terrestris, a medicinal herb. Plant Cell Rep. 27: 519-528. http://dx.doi.org/10.1007/s00299-007-0478-5

Silva MDS, Pereira AMS, Morel LF, França SC, et al. (2013). Association of loganin contents with the genetic characterization of natural populations of Palicourea rigida Kunth determined by AFLP molecular markers. Biochem. Syst. Ecol. 51: 189194. http://dx.doi.org/10.1016/..bse.2013.08.032

Smouse PE, Dyer RJ, Westfall RD and Sork VL (2001). Two-generation analysis of pollen flow across a landscape. I. Male gamete heterogeneity among females. Evolution 55: 260-271. http://dx.doi.org/10.1111/j.0014-3820.2001.tb01291.x

Vos P, Hogers R, Bleeker M, Reijans M, et al. (1995). AFLP: a new technique for DNA fingerprinting. Nucleic Acids Res. 23 : 4407-4414. http://dx.doi.org/10.1093/nar/23.21.4407

Wright S (1978). Evolution and the genetics of populations. The University of Chicago Press, London.

Young A, Boyle T and Brown T (1996). The population genetic consequences of habitat fragmentation for plants. Trends Ecol. Evol. (Amst.) 11: 413-418. http://dx.doi.org/10.1016/0169-5347(96)10045-8

Young AG and Clarke GM (2000). Genetics, demography and viability of fragmented populations. Vol. 4. Cambridge University Press, England. 